November 2013

\title{
Narrative Strategies of Post-Genocide Argentine Filmmaking: The Decade of the 1980s
}

Lior Zylberman

CONICET-Genocide Studies Centre - National University of Tres de Febrero-Argentina

Follow this and additional works at: https://digitalcommons.usf.edu/gsp

\section{Recommended Citation}

Zylberman, Lior (2013) "Narrative Strategies of Post-Genocide Argentine Filmmaking: The Decade of the 1980s," Genocide Studies and Prevention: An International Journal: Vol. 8: Iss. 1: Article 8.

DOI: http://dx.doi.org/10.5038/1911-9933.8.1.6

Available at: https://digitalcommons.usf.edu/gsp/vol8/iss1/8

This Articles is brought to you for free and open access by the Open Access Journals at Digital Commons @ University of South Florida. It has been accepted for inclusion in Genocide Studies and Prevention: An International Journal by an authorized editor of Digital Commons @ University of South Florida. For more information, please contact digitalcommons@usf.edu. 


\title{
Narrative Strategies of Post-Genocide Argentine Filmmaking: The Decade of the 1980s
}

\author{
Lior Zylberman \\ CONICET-Center for Genocide Studies, National University of Tres de Febrero, Argentina
}

\begin{abstract}
Summary: This work is part of a broader study. This article analyzes Argentine films about the genocide perpetrated by the country's last military dictatorship (1976-1983). The focus is on the films produced during the 1980s, specifically those made between 1984 and 1989. Generally these films have been analyzed from an aesthetic perspective, or else from a chronological standpoint that connects their historical context to the design aspects of individual films, their mise-en-scène. Central to this latter approach has been what is termed a prevailing "theory of the two demons". This approach is generally valid, however this article posits that in their narrative strategies - that is, their plots, ideas, and stories-Argentinean films from the late1980 s present a wealth of elements that exceed such narrow theorizing, in the process enabling comparisons and contrasts with other studies of the country's genocide.
\end{abstract}

Keywords: Argentina, films, representations of genocide, narrative strategies.

Date of peer-review approval: May 6, 2010

\section{Introduction}

Film does not exist on the periphery of its time. Today, it observes and passes judgment on the course of world events. In the social sciences, film has become a valid tool for studying society. ${ }^{1}$ According to Robert Rosenstone, ${ }^{2}$ a leading scholar working on the relation of history and film and who wonders what can be known and understood historically in cinema, there are many questions concerning cinematic depictions of the genocide perpetrated by Argentina's military dictatorship between 1976 and 1983 . Like Rosenstone, this author perceives films as documenting and circulating understandings of, and therefore judging, the world of the past. Though the business of cinematic analysis can be approached in different ways, this article will concentrate primarily on cinematic narrative. More specifically, this article will appropriate an analytic model suggested by one of the most important studies of the relationship linking film to the genocide of the Jews, Annette Insdorf's Indelible Shadows. Like Insdorf, though with reference to films about Argentina's last dictatorship, filmmakers' narrative strategies expressed in a variety of films from the 1980s will be considered, paying special attention to the recurrence in them of specific visual motifs and narrative themes. ${ }^{3}$

Cinematic production of the later 1980s has been pushed into the background of critical analysis in recent years; partly as the result of the rise of a certain view according to which films produced in the early years of Argentinean democracy remain overly indebted to what has been termed the 'theory of the two demons." In other words, it has become commonplace to view cinema of this period as ambivalent in its moral equation of the crimes of the state with efforts to resist the dictatorship. ${ }^{5}$ Though many criticisms of these films can be (and have been) made with respect to their avoidance of politics and flawed presentation of the victims of violence, ${ }^{6}$ this article will address the successes of these films.

Thus, I propose departing from the more usual 'two-demons' view in order to obtain critical distance sufficient to buttress a more nuanced and substantial account of late-1980s Argentinean cinema. In Argentina, it is well known that the Unión Cívica Radical ${ }^{7}$ government generated the 'theory of the two demons' in order to explain political violence during the preceding years of dictatorship in a manner intended to forestall potentially catastrophic demands for retribution, and certainly this view penetrated many works of art, including films. ${ }^{8}$ Nevertheless, it must be remembered that all films appropriate social discourses and then supplement and alter them using the vast array of narrative conventions and formal techniques available to their makers. In accordance with the possibilities inherent in the medium, film writes history, questions it, and re-presents it. ${ }^{9}$ But as Rosenstone asks "what historical reality do these films re-construct? What meanings do these historical realities hold for us?"10 


\section{Some Explanations Regarding Analytical Strategies}

In the chronological framework of the Argentine genocide developed by Daniel Feierstein, ${ }^{11}$ 'symbolic enactment' occurs last, and manifests itself in struggles over memory, trials, denials, and ways of working through trauma. Clearly, filmmaking and the particular cinematic works discussed in this article contributed to these symbolic processes. Yet it remains important to think about the many levels of social development or dysfunction in a post-genocide society, and to identify what the effects of genocide were in the past and are in the present. If what Feierstein terms a "reorganizing genocide"12 seeks a transformation in social relations, we must look at how these new relations are portrayed. In the case of filmmaking, as Claudia Gilman, author of Entre la Pluma y el Fusil, has argued, the Argentinean dictatorship served to terminate the film experiences produced between 1960 and 1970. In the dictatorship's wake these experiences could not be repeated, not only because the filmmakers disappeared or were exiled, but also because of changes in modes of film production and in the use of political films. ${ }^{13}$ The films of Fernando Pino Solanas are emblematic in this regard. Upon returning to Argentina from exile in 1983, Solanas threw himself into making fiction films under the democracy $\left({ }^{14}\right)$, but he did not return to political-documentary filmmaking until relatively recently, early in the twenty-first century. Likewise the turn toward neoliberalism begun under the dictatorship (1976-1983) brought with it substantial changes in political and economic practices, as well as in social relations. On a more micro level, the dictatorship's promotion of an atmosphere of distrust among citizens seemed to be one of the most effective ways to close off cooperative or friendly social relations. It was not possible under such conditions to build a critical or anti-establishment consensus, or to marshal a broadly collective dissenting political will, leaving self-exile, such as Solanas chose, one of the few viable political options left open to people individually. The terror and fear omnipresent during genocide does not vanish and is not overcome when the regime responsible for it ceases to be. Fear not only paralyzes, it also produces debilitating and enduring uncertainty. Art in general, and film in particular, is one of the available ways of exorcising this fear, of coping with the past, and of achieving some kind of catharsis. ${ }^{15}$

Just as Jordi Balló has developed an account of cinematic visual motifs in his book Imagenes del Silencio, this analysis approaches narrative motifs not just as story elements and elements of style but as a means of coordinating and grouping different film texts. These motifs, in their repetition and evolution within individual works and distribution across works of cinema, do more than just tell; they also show something. Three motifs are of particular concern here: (1) the camp; (2) killers and their accomplices; and (3) victims. This analysis of these motifs, which does not claim to include all the films produced in the relevant period, nevertheless allows for the comparison of several films which, taken together, reveal a great deal about atrocity's post-memory and lingering effects.

\section{"The camp"}

Though 'the camp' was an essential part of the methodology of the kidnapping-torture-disappearancedeath process employed by the Argentinean junta, there are actually very few films with plots set in these carceral spaces. Sometimes the camps are mentioned, and at other times they are filmed from the outside, but rarely are their interiors revealed. One possible reason for this absence has to do with the fact that, unlike with the Holocaust, where there is abundant visual material documenting the specifics of concentration camps both during and immediately after their operation, in the case of Argentina there is none. No visual or cinematic record of the camps and detention centers used during the dictatorship exists. The images that have reached us come from the time when these sites were already destroyed or else were being used for other purposes. Consequently, much of what we imagine regarding incarceration by the military regime derives from other modes of representation such as the oral testimony of perpetrators and survivors.

The term 'the camp' is used here in discussion of representations of the Argentinean dictatorship to refer to a disciplinary technique, a device for social indoctrination. Surviving the camp is shown by filmmakers to be part of the logic of spreading and proliferating the horrors of the repressive state, as is seen, for example, in my subsequent discussion of the freeing of Pablo Díaz in La noche de los lapices (Héctor Olivera, 1986), or in the threat to have the protagonist Sixten witness a torture session in Los dueños del silencio (Carlos Lemos, 1987), a scene that is similarly depicted in Alberto Fischerman's Los Días de Junio (1985).

'The camp' represents the site of the cancelation of identity, perception, and mobility; it is the place in which "the most absolute conditio inhumana"16 is realized. "The camp' is at the heart of what Giorgio Agamben terms a 'state of exception', a zone of profound vulnerability and exposure to violence wherein there 
is no distinction between exterior and interior, exception and rule. In turn, within the camp there arises a new and extraordinary logic, complete with its own lexicon and 'rituals'. The population of Argentina's camps, in addition to persons who were kidnapped and disappeared, was comprised of perpetrator groups known as patotas (gangs) or grupos de tareas (task force), groups that carried out torture. Due to their physical proximity to the world existing 'on the other side of the wall', these camps were only able to exist in "a society that chose not to see, because of its own powerlessness, a society that had disappeared, as crushed as the kidnapped persons themselves." ${ }^{17}$ Let us recall the words uttered by Argentinean writer Osvaldo Bayer as he is walking through the streets of his neighborhood in Carlos Echeverrías documentary film Cuarantena (1984). While watching some children playing on the sidewalk, Bayer observes that behind the quiet facades of the surrounding buildings, "we have forgotten that the worst also occurred there: crimes, shouts, kidnappings, terror, and indifference".

Given the lack of actual images of the Argentine camps, the spectator who has not been exposed to any direct visual references to camp space can only imagine it. In Argentinean atrocity cinema this imagining is evoked through three different means or strategies: through images of absence; the depiction of actions inside 'the camp'; or the metaphorical evocation of 'the camp'. For example, in the section of Rodolfo Kuhn's documentary Todo es Ausencia (1984) devoted to Hebe de Bonafini, she and the viewers survey the remains of La Cacha, a concentration camp located near Olmos Prison where one of Bonafini's sons spent more than two years. The camera pans the area and we see only ruins, empty buildings, clumps of grass and groves, in an exercise of visual free association that encourages comparison with Alain Resnais' use of color footage in his landmark Holocaust documentary Night and Fog (1955). The title of Kuhn's documentary (Everything is Absence) is consistent with what Bonafini shows us: absence and remnants; the remains of La Cacha are silent witnesses to the torture and death that occurred there.

The flawed La Noche de los Lápices, Héctor Olivera’s 1986 dramatization of a nonfictional account of events comprising the so-called 'Night of the pencils', during which seven students were abducted after protesting a rise in bus fares in the city of La Pata, was the first film, and for a period of ten years the only film, to shoot a great part of its dramatic action in the interior of a re-created camp. Thus it enables viewers to observe the state's methods of torture and confinement almost in their totality, ${ }^{18}$ from kidnapping through to liberation, at least in the case of protagonist Pablo Díaz, who, unlike his less fortunate companions, was transferred to legal detention and later released. This film clearly develops an account of the logic of 'the camp': we observe the wiping out of individual identity, and also the constraints placed on detainees' perception and mobility; the young people are blindfolded and immobilized, semi-naked and dirty. The 'initiation' through torture is also seen in this film. The violence of the act itself does not become entirely explicit, but viewers do see the parrilla ${ }^{19}$ as well preparation of an electric cattle prod, and are shown the experts in torture who get to decide whether the prisoners will live or die. One of the torturers says: "You're going to live if I want you to, do you get it?" Meanwhile, the authorities bring in a friend of Pablo's to make him 'betray' information about his companion. Trails of smoke rising at exactly the moment when Pablo enters the camp serves to emphasize the feeling that the place is gloomy and hellish. Inside, the people who have been kidnapped meet kind and evil guards, are visited by a priest, and then are taken to a partially mock execution where a kidnapped Montonero is shot. Although the appropriation of babies is not a topic that the film deals with in depth, one of the girls depicted is pregnant, and we are given to understand that when she gives birth she will be 'transferred' and her baby taken from her. Inside 'the camp', in spite of the brutalization that has been brought about, the young people, especially Pablo, manage to establish mutually supportive relationships, primarily relating to food. There is even talk of the future of Pablo and Claudia, contrary to the wishes of the former, and this is show to every day functioning as a means of resistance and personal (if imagined) escape from the rigors of incarceration. The wide circulation of Olivera's film and its use in schools and universities allowed large audiences for the first time to witness state abuses in its camp system from inside. Along the way, the film helped to establish the conventions and iconography used in subsequent representations of the concentration camp during Argentina's genocide.

In Carlos Lemos' 1987 Los Dueños del Silencio, 'the camp' signifies primarily as a disciplinary mechanism. The film's protagonist, Sixten, is a Swedish journalist who has come to Argentina to investigate the disappearance of a woman who is a citizen of Sweden. Loosely inspired by the Hagelin case ${ }^{20}$ Sixten pretends to be a businessman and manages to obtain an introduction to a group with a list of the names of disappeared persons which, using Sixten as an intermediary, they intend to deliver to Swedish authorities. The group includes the father of the Swedish girl, as well as a priest. Running parallel to Sixten's quest, a blond 
military man identified as the Captain in charge of 'the School', a clear reference to ESMA (the Navy School of Mechanics that was used as a well-known concentration camp), suspects that the arrival of this foreign businessman is a front. He sets about determining Sixten's real identity, and eventually follows and kidnaps him. Once in 'the School', the Captain shows the facilities to Sixten: not much of 'the camp' is seen, only offices and a few bedrooms, one of which, empty, contains a parrilla. There the Captain shows him an electric prod and teaches him about the procedures used to forcibly extract information. Sixten watches and recognizes the Captain's veiled threat. Nevertheless, Sixten manages to obtain the list of names and prepares to leave the country. At this point, he is abducted to 'the School', and there led to a room in which several persons are shackled and blindfolded, including a girl belonging to the resistance group with which Sixten has had contact. The Captain demands the list; Sixten claims to know nothing about it. The girl is then taken to be tortured and Sixten is forced to witness it. The film cuts to a task group searching the hotel where the Swede is staying and shows them finding the list. Sixten returns to his country, and because of his confession about the lists, the entire group collapses. In this way Lemos shows his viewers how the camp functions as a disciplinary mechanism. The terror it elicits is increased not only through its impositions on victims' bodies but also on the demands it places on people's minds, on its exploitation of fragile psychologies. When Sixten is forced to witness the torture session he has been degraded on both a tangible level and a symbolic level.

Juan Carlos Desanzo's Los Días de Junio, En Retirada (1984) and Rodolfo Kuhn's El Señor Galíndez (1984), offer us similar cinematographic interpretations of Argentinean camps. In Los Días de Junio, friends are blindfolded when taken to a detention center. On the one hand, the friends 'confess' to each other about their inaction against the dictatorship; on the other, sharing this extreme situation sustains their friendship. When they realize that there is nobody else in 'the camp', that the task group responsible for bringing them and beating them is not there either, they then try to escape. The friends soon realize that the site has been abandoned, and that it lies right in the midst of the city, indeed next to the bookstore belonging to one of the friends. In this way, Los Días de Junio informs us of the close proximity of these camps to the goings on of everyday city life.

El Señor Galíndez, based on a play by Eduardo Pavlovsky, ${ }^{21}$ can be read as a diptych, a companion piece to another film made by Kuhn, the documentary Todo en Ausencia in which relatives of the disappeared discuss their feelings about what has happened. Pavlovsky's text was set on 15 January 1973, and made a clear allusion to the previous dictatorship, conducted by General Agustín Lanusse, after the Proceso de Reorganización Nacional. ${ }^{22}$ The language in the text takes on a euphemistic nuance, and that was Kuhn's intent. The carceral space in question lies in the basement of a large house in the middle of nowhere. The house is lost in the middle of a forest, and two torturers come to work there. When Galíndez notifies them by phone that they will soon have to begin their brutal work, Kuhn utilizes a technique described by Pavlovsky as follows: "the setting was transformed from an ordinary room into a torture area." ${ }^{23}$ That is, in its audiovisual staging, in a more metaphorical form, Kuhn recreates the torture chamber as a clear allusion to the lexicon of genocide: the torture chamber becomes a real quirófano, an operating room.

A similar staging inspires Juan Carlos Desanzo's 1984 crime drama En Retirada. In the film, El Oso (The Bear, played by Rodolfo Ranni) ${ }^{24}$ a member (ex-member?) of a task group that during the fall of the regime must "be guarded", returns to his village where he reencounters an old girlfriend. Days later, he sees her with another man. He later breaks into her house, removes a mattress from a bed in the bedroom, strips the woman, and ties her to the bed, thus creating a parrilla in the everyday setting of a home where the windows face outward. The bedroom of a family home is thus cinematically transformed into 'a camp'. El Oso continues on with the process: he beats his ex-girlfriend, turns on the radio, and breaks a table lamp to use as a cattle prod, thereby forcing her to talk. Then he heads to the mechanic's workshop where the supposed lover works and shoots him at point-blank range. In this way En Retirada suggests to us that the methods of terror function even outside of space of 'the camp'.

In Luis Puenzo's award-winning La Historia Oficial (1985), 'the camp' is not present in images, nor may it be found in metaphorical allusions. Instead, 'the camp' appears in the story of Ana. The film, which takes places in the final months of the military regime, puts into images and words the situation of the survivors. In one sequence, Ana, a woman just returned from exile, tells her friend Alicia about the operation in her house, then about the taunts and tortures suffered in the camp, about what was done to the pregnant women. ${ }^{25}$ Although the dialogue occurs while the friends are drinking alcohol, the delivery of Ana's story approaches the giving of testimony. Facing Ana, Alicia only asks her whether she made the corresponding denunciation. This scene, therefore, shows us two suggestive elements: first, the the survivor's problem, which include a lack 
of people who want to listen to them, and disbelief of their story; second, the evocation of 'the camp' and the methods of genocide through the words of Ana.

In Carlos Echeverría's documentary Juan, Como si Nada Hubiera Sucedido (1987), a documentary about Juan Herman, the only abducted in the Patagonian city of Bariloche, the appearance of 'the camp' is presented in a similar way, through attention to the spoken word. Echeverría uses the stories of various witnesses as the basis for creating visual images; in this way, starting from the present, the camera travels to the places where Juan himself went, showing us how the city of Bariloche (and indeed the entire country) continued its daily life while concurrently on the streets there was kidnapping and murder. Even though the film's coverage of the trial in the Herman case does not contribute enough knowledge about Juan's fate, a documentary report is given by Miguel Ángel D’Agostino, a survivor of the concentration camp known as El Atlético. ${ }^{26}$ It is in Miguel's narrative that 'the camp' appears; he tells viewers the details of daily life in 'the camp' and also relates what became of Juan. Utilizing a technique similar to that employed in Bariloche, while D'Agostino speaks we see images of a controlled-access highway and the remains of the place where El Atlético operated. In a similar way to Todo es Ausencia and La Historia Oficial, the story serves us as a substitute, that is, as a means for imagining 'the camp. The images of the debris, the remains, added to the stories of the people bearing witness, offer us a way to channel our imagination so that we realize what occurred in those ruins; thus the highway ceases to be a mere highway, as does the abandoned structure.

\section{Killers/Accomplices}

What causes and leads a government to engage in genocidal practices? How is a policy of extermination made viable and normalized? How, in the words of Lifton and Markusen, ${ }^{27}$ is a genocidal mentality brought about? Insight into the answers to these questions may be found in Miguel Pérez's documentary La República Perdida II (1986), which develops an account of the genocidal ideology asserted in the National Security Doctrine. ${ }^{28}$ Likewise, Jorge Denti's film Malvinas: Historia de Traiciones (1984) not only analyzes the military conflict between Argentina and Britain in the South Atlantic, but considers it a continuation of the genocidal practices and social and economic reorganization of the country more generally.

Thus the conformation to the genocidal mentality is found in numerous players among the perpetrators. La República Perdida II takes pains to provide images of the ideologues: the military leadership of the first two Military Juntas, as well as establishment figures from the Argentine rural and financial sectors. Fictional cinematic works, however, tend to present other types of perpetrator: the bureaucrats and the executing arm, "the arm that obeys a voice that thinks". ${ }^{29}$ It is a hierarchy under which the lower one descends, the closer one comes to a crime involving bloodshed.

Systematic extermination requires not only experts in death but also other kinds of specialists, such as doctors, many of whom may be counted among the perpetrators. The personality of these specialists also can be thought of in terms of their propensity for "amoral reasoning": their tendency toward rational calculation and a preoccupation with efficiency, which in turn eclipses all subjective and ethical concerns. Argentinean films made in the 1980s have revealed, in a way that is unmatched, the complexity of the perpetrator, allowing us to see (and think about) the different kinds of perpetrators. Lifton argues that that genocide is changed into an absolute form of murder in the name of healing ${ }^{30}$. At the same time, the psyche of the perpetrator has been conditioned by language, thanks to the use of euphemisms, as well as by the splitting of the personality, not into two identities but "into two functioning wholes, so that a part-self acts as an entire self". ${ }^{31}$

In the film adaptation of El Señor Galíndez, the action not only takes place in 'the camp', in the operating room, but also in the home of Beto, one of the torturers. The perpetrator's 'split personality' proposed by Lifton gains a richer meaning in this film, for Beto has a family, a wife and a child. We see that he is concerned about his daughter's health and education; clearly he is an affectionate father. He even phones from 'the camp' itself to make sure everything is all right at home, asking to speak to his daughter so that he can say goodnight to her. Euphemism is used in a recurring way by the torturers; they speak of "parcels" and of "the job" they must do. Beto and Pepe, the other torturer, clearly belong to the lower part of the hierarchy of perpetrators. The calls of Galíndez - whom we neither see nor hear, we only know that he calls on the phone- function as the voice that thinks, with the pair of torturers serving as the arm that obeys. Even though both express certain doubts regarding their task, periodically the voice urges them to fulfill their mission, thus reaffirming the importance of the task to be performed. Eduardo is the new man who has come to complete his education and join the team; he claims to have read all Galíndez's manuals and mentions, looking at the camera, "the enormous effort of vocation that our profession involves. Only with faith and will can one achieve the mental 
adaptation necessary for the success of our task; faith and skill are key for a group of men privileged with an exceptional mission." Here the amoral reasoning of the torturers is captured both in dialogue and in the actions performed by the actors. It is clear that their amorality does not merely reveal them to be obedient lackeys; on the contrary, the revelation of their split personality helps us to understand the way perpetrators manage to protect themselves psychologically. In other words, perpetrators are more than simply blindly obedient. Beto and Pepe are aware of the power they possess and the purpose for which they use it: "you have to think that for each job well done, thousands are left paralyzed by fear", they tell Eduardo- a very clear allusion to fear as a technique, a method to achieve a result.

Similarly, they are convinced of the public service they offer, based on one of Galíndez's manuals: "the values of society must be preserved, the homeland, the family, and property". Another interesting dialogue between the two specialists concerns their job future: Beto is studying accounting, with a view to other work horizons, since he has "a family to support". He senses that the work they are currently dedicated to will not last forever; on the other hand, Pepe suspects that, given the important social function they are performing, they will never leave this job. Certain scenarios that will be returned to later by other films are suggested here: on one hand, the 'unemployed workforce', as will be seen in En Retirada; on the other, Beto's foresight in "expanding his work horizon" is something we see in the appearance of an airline pilot who was also a pilot on the death flights. ${ }^{32}$ Thus, El Señor Galíndez exhibits certain elements of the psychology of the perpetrator: the torturer as worker and as expert, even as bureaucrat. ${ }^{33}$ Similarly, the filmmaker exhibits part of what Helen Fein called the 'universe of obligation', "the circle of individuals with reciprocal obligations to protect each other whose bonds arise from their relation to a deity or sacred source of authority". ${ }^{34}$

As mentioned previously, La Noche de Los Lápices was the first film to locate its action inside a 'camp'. This film exposes methods of genocide and thereby exposes the killers. Not only is the task-group that kidnaps presented to the viewer, but also a group of torturers and their behavior. Simultaneously, there is a judge who orders and conducts the questioning; thus a part of the descriptions of modern genocide is on show: a division of labor that is likened, to a lesser degree, to the scale of industrial production. Also as part of the generic structure of the film - elements which will be addressed infra- the perpetrators here are described as being absolutely evil, verging on sadism, which deprives this film of the psychological complexity displayed in Kuhn's movie.

En Retirada presents us with various suggestive elements for analyzing the perpetrator. This film locates its action in the final months of dictatorship, the task groups have been urgently requested "to protect themselves": now it is the turn of democracy, says Arturo to El Oso; thus the film tells us of El Oso's plans to retire. The film proposes two possible options for these withdrawals, first, the route taken by Arturo, who now runs a pawn shop, suggesting that the business of the perpetrators is based on the objects of value taken as spoils during the operations. Arturo is also El Oso's boss, leaving us to wonder whether he is a mere civilian or someone who also belongs to the security forces. Despite everything, he is higher ranked within the security forces than El Oso. After the dictatorship ends, Arturo is now a businessman. In turn, El Oso, who is recognized by a man as the person who kidnapped and tortured his son, is located lower on the hierarchy of the perpetrators: he is the hand that obeys the orders. Thus El Oso is unable to leave the past behind. If Beto in El Señor Galíndez had a split personality, an amoral way of reasoning, El Oso repeats his work philosophy in his daily life, as mentioned above when discussing the narrative strategy of the camp. Despite the warnings from his boss, El Oso cannot go into retirement. He is unemployed, he no longer wants money, and yet there is only one thing he knows how to do. Thus, as an act of rebellion, El Oso tries to sell his story to the press, but the press does not want stories, it wants images, faces. At the same time, El Oso does not know that his peers are watching him, with their actions culminating in his murder in pursuit of preserving the pact of silence.

"You want me to talk? You want to have the scoop? Is this an interrogation?" These are some of the words exclaimed by the former Colonel, now Brigadier General (retired), Castelli in Juan, Como si Nada Hubiera Sucedido. This military man, among the many interviewed for this documentary, claims that he doesn't know the fate of Juan Herman, despite having been a member of the top military authority in the zone in which Herman was abducted during the dictatorship. ${ }^{35}$ Nevertheless, in front of the cameras he denies all knowledge of the case. Even though the film can neither penetrate nor break the pact of silence, it manages to put into images the face of one of the perpetrators, who was in charge of the military zone to which Bariloche belonged. Juan thus presents us with the face of the military hierarchy during this era; and lest we see only a man in ordinary clothes while he gives his testimony, we see at the same time photographs in which he is dressed in uniform or in fatigues. It is worth remembering that this man was part of Operation Independence. ${ }^{36}$ 
The same is true of Colonel Zárraga, the principal figure in the political repression in Bariloche during the years of 1976 and 1977, who headed all the security forces in the zone. In the interview of this colonel, two types of testimonies follow: the first, in which he answers by using a rather rigid vocabulary and even a rigid posture, he asserts that the Herman case "was a surprise, because it was the only incident whereby the investigations yielded negative results... I can't give details because I don't know them. I don't know the father." The statements clearly reflect the pact of silence. In turn, when Zárraga thinks that the camera has been turned off and Esteban Buch, the journalist who made the investigation, is asking him about the reasons for the kidnapping, he alleges that it could have been another force or possibly "the people themselves where he was put". He also states that he knew the young man, since Dr. Herman (Juan's father) was well known in Bariloche, and also that he was informed of the case while at a party with Colonel Castelli. Yet he also asserts that "no other type of operation was carried out in Bariloche, therefore, thank God, I am not on any list". Thus we are witnesses to the colonel's contradictions, as the camera manages to weaken the perpetrators' pact of silence.

If in La Noche de Los Lápices the perpetrators were presented to us as evil beings, in Los Dueños del Silencio the torturers are shown from a similar persective as the torturers in El Señor Galíndez, that is, as human beings. In Los Dueños del Silencio, the Captain, too, has a family, and he is presented to us as an affectionate father, concerned about his daughter's birthday party. Even though the Captain participates in the operations and the kidnappings, and is the one who kills a Swedish teenager on the street, both he and his second-in-command are not presented to us as "monsters", but as people pursuing a political plan. Just at the end of the film, when archival images are used to condemn the amnesty laws of 1986 and 1987, we see the Captain on horseback, in slow motion, next to two women, a clear metaphor for 'freedom. This 'freedom', which in truth we ought to call impunity, is also demonstrated in the way in which the character's psychology of El Oso develops in En Retirada.

Genocide, like every other crime, has complex causes and provides a host of benefits for perpetrators. Therefore, analyzing genocidal practices in film plots entails delving into these issues as well. Genocide requires, besides executioners, planning, tools, mechanisms of subjugation, and especially accomplices; ${ }^{37}$ people who do not get their hands dirty and nevertheless are the ones who contribute to developing the genocidal mentality: intellectuals, economists, lawyers, journalists. How do we see the figure of the accomplice in the corpus of films dealt with here?

In Todo es Ausencia (Rodolfo Kuh, 1984) the camera accompanies Marta, ${ }^{38}$ one of the protagonists and a Mother of Plaza de Mayo (an anti-government civil society group), to a church. She refers to the impassioned speeches and homilies of Monsignor Victorio Bonamin, the military bishop, and of Miguel Medina, the vicar general of the Army. Marta does not speak to the camera; she talks to a Spanish priest, and she supports, and denounces, the Church as an accomplice in genocide: "I don't mean the Church, but rather the ecclesiastical hierarchy of the priests and nuns, complicit in every aspect of the dictatorship." Coming from a Catholic and conservative family, Marta expresses her disappointment with the Catholic Church in Argentina, and tells how, in Rome, Cardinal Primatesta was unwilling to receive her because he did not want her to involve him in the complaints and to be associated with her. Similarly, Archbishop Pio Laghi said to her: "either they're very tortured and the military is not going to release them, or they're dead".

As images of the Argentine ecclesiastical hierarchy and the members of the military junta follow one another on the screen, Marta says, "so, the genocide is not being carried out from night to morning, and they alone (...) it's the society, the Church (...) all those who could do something for my husband, did nothing." With great sadness, Marta asks the priest what to do so that she can accept all this. She speaks out against the Catholic inmates who were in the concentration camps, saw how people were tortured, and were silent: "this complicity of the Church is terrible." In the scene where Alicia, the protagonist, talks to a priest in La Historia Oficial, we see a similar situation. There she demands that he tells the truth about her adopted daughter; a truth that he already knows, as he is familiar with her daughter's origin, but does not want to talk about. The visit of a priest to the camp in La Noche de Los Lápices is not a minor effort involving a complex labyrinth of complicity, nor are the facts stated and presented in images in La República Perdida II regarding a sector of the Church headed by Monsignor Victorio Bonamin, who says, "the coup was an act of providence and, as time passes, it will be seen that it was a work of God". It is this same film, also, that presents the financial sectors and the Argentine rural society as accomplices.

In La Noche de Los Lápices, we also see Claudia’s mother attempting to find information about her missing daughter, file the appropriate report with law enforcement, and being turned down by the police commissioner. The mother asks to speak with a bishop, who refuses to receive her and also claims to have 
forgotten the favors done him by Claudia's father in past years. Finally, it is the monsignor's secretary who receives her and tells her "that she should accept it with Christian resignation", and that she will not see her daughter again.

Yet we must not think of the accomplices as being exclusively in the ecclesiastical hierarchy. In La Historia Oficial a new kind of accomplice is introduced: the businessman. In this film this figure is embodied in Alicia's husband, Roberto. During the film, Roberto's own father, in a scene where they share a family lunch in a noticeably tense atmosphere, accuses his son of being an accomplice: "the whole country went downhill, only the bastards, the thieves, the accomplices, and my oldest son moved up". In exchange, Roberto asserts that what his parents said is "anarchist crap. They want to make me feel guilty because I'm not a loser." At that same lunch, Enrique, Roberto's brother, takes exception to the 'war' to which Roberto alludes, asserting that the costs are going to be paid by "kids like mine (...) by not eating and not being able to study. What are you going to pay!" Roberto's complicity does not end with the support from the economic sector, which he represents. Roberto has contacts with a general, and it is with this general that Roberto does business. Roberto is one of those who have benefited from the genocide, Roberto is an indirect perpetrator, and it is thanks to his contacts that he brings Gaby, his little daughter, home one day. The character of Roberto personifies the backing and the complicity of certain sectors of civil society with the armed forces in carrying out the genocide. In this way, in the seizure of that infant, Roberto is transformed into an accomplice and performer of genocide, putting into practice one of the aspects theorized by Raphael Lemkin at the time the genocide was conceived of and planned: destruction of identity and imposition of a new identity. ${ }^{39}$

In the character of Barbieris in Juan, Como si Nada Hubiera Sucedido, we see the support of certain financial and industrial sectors that become complicit in the genocide. Barbieris, owner of a travel agency, held the position of quartermaster during the military intervention. The economic elite of Bariloche, chiefly concentrated in tourism, were a fervent supporter of military governments. Economic and political interests are brought together in the Association of Hotels and Travel Agents (of which Barbieris was president) and in the Chamber of Commerce and Industry. The government always favored these associations (and this means during the different dictatorships) at the times of involvement of unions, above all the gastronomic workers' union. Esteban, the investigator of the documentary, confirms that Barbieris never showed solidarity with the Herman family. In fact he rejected the Herman family, in a straight cut, during the interview. We see photographs of Barbieris as quartermaster, hand in hand with Colonel Castelli. ${ }^{40}$ The circle closes: the inhabitants of Bariloche preferred tourism to knowing what happened to one of their sons.

\section{Victims}

The debates with respect to the representation of victims, especially in the 1980s, have been addressed from different points of view. The criticisms were based on the depoliticizing of the victims' identities and also on the spreading of the 'theory of the two demons', as mentioned in the introduction to this article. Therefore, the present narrative strategy will be divided into two parts. The principle of 'reorganizing genocide' ${ }^{41}$ seeks not only to exterminate bodies but also to remodel social relations by means of terror, destroying all possibility of independent and anti-establishment relations, and establish a hierarchical society that is ideological, religious and cultural. Political and social activists, intellectuals, and trade unionists were systematically persecuted and murdered for the purpose of dissolving past experiences by exterminating the individuals who personified critical, anti-establishment, and supportive caring social relations. There also was an attempt to use terror and annihilation to end those relations as a whole.

One of the theories this author has presented elsewhere ${ }^{42}$ has to do with films that begin either with the extermination phase already in progress or evolving at a later date. Thus, many of the film productions put aside economic, political, and social processes and conflicts, not only those of the 1970s, but those of the previous decade as well. In considering this mode of emplotment, we see that the focus is placed primarily on repression. However, we can find some films such as La Noche de Los Lápices or Sentimientos: Mirta de Liniers a Estambul (Jorge Coscia and Guillermo Saura, 1987), that begin the story during the last months of the Peronist government. The former focuses on the campaign of the high school students for a secondary school bus pass. The latter focuses on the atmosphere that existed at the university, due both to political activism and to the first signs of persecution inside the lecture halls. On the same theme, La República Perdida II begins with the death of General Juan D. Perón, establishing with his demise the end of an era.

Despite the criticism regarding the political identity of the victims, I argue that re-politicization rather than de-politicization evolves in the films plots. That is, the treatment of the political or activist identity of the 
victims produces a new politicization, the result of the new political practices ensuing from the practice of genocide. In the various films chosen here for analysis, the political aspect, and the site of political practice in general were toned down. The students in La Noche de Los Lápices belong to UES, the Union of Secondary School Students, and to Guevarist Youth as well. ${ }^{43}$ We observe, in these films, the campaign for the secondaryschool bus pass, the literacy efforts by the young people and their attempts to set up canteens and do grassroots organization. Pablo Díaz, one of the protagonists and the only survivor of his group, himself hands out flyers about Che Guevara in the slum. Likewise, from the posters of Eva Perón ${ }^{44}$ that some of them have in their rooms, we can infer their backing of the Peronist Movement and even, given the way in which her standing was restored by the Montoneros, ${ }^{45}$ their agreement with that group.

In Todo es Ausencia, Marta Bettini tells us about her son, Marcelo, who"consistently carried out the celebrated social doctrine of the Church. They shared with the poor. My children, like so many students at Marist schools, were sacrificed in those days for their faith, for their conviction that they were doing what they ought to do. What we were not capable of doing. We admired them for that commitment." The commitment referred to by Marta centers on social work and political activism in the slums. In that same film, Hebe de Bonafini ${ }^{46}$ talks about the activism of her disappeared children. There, she says, "when my son [Jorge] was 16, he asked me the first question: Mama, what is it that we have to give? From that moment on, I started to see other things. My children got involved in activism, and there were many needs." In Jeanine Meerapfel's La Amiga (1988), a film about the inception of the Mothers of Plaza de Mayo, María's son is kidnapped in the slum where he was an activist. The father of Juan Herman, in Juan, Como si Nada Hubiera Sucedido, states that his disappeared son "was interested in social problems, was concerned, and would have liked to solve them if it was in his hands. At the university, he probably was active in the movements that were seeking greater social justice. He went to slums and saw things with his own eyes. He didn't want to stay with the newspapers; he wanted to see for himself. And always from the perspective that defended the rights of the ordinary people and the possibility that people might have a better life." The father's words are complemented by the testimony of Eduardo, a school friend of Juan's; he confirms that “after Perón's return, there started to be factions with a new ideological direction, and at that moment both Juan and I felt a sense of identification with what the JP [Peronist Youth] was".

Some of the changes in social relations among the friends in Los Días de Junio have already been mentioned above. Turning to the victim as narrative strategy, in this film a brief mention is made of the Peronist affinities of one of the characters, and also of the socialism linked with the figure of Alfredo Palacios. ${ }^{47}$ Nevertheless, when the flag that symbolizes their friendship is prepared, it has a five-pointed star at its center. Even though it refers to the fact that at that time there were five friends, this star also evokes the star of the ERP, the leftwing People's Revolutionary Army.

\section{Criticisms, Outcomes and Conclusions}

Analyzing the films produced immediately after the perpetration of genocide has its difficulties because of the immediacy to the event and the short time to elaborate, both in a social and artistic way, the consequences of the genocide. There have been important academic works about this topic; however, in this article, an analysis has been attempted, very concisely, of the first productions from the perspective of the genocide studies.

Let us dwell for a few moments on the case of the Holocaust, which took several years to be brought to the 'big screen'. Even though the first films about the Nazi concentration camps were made primarily after the war ended (although some had been produced even during the war), movies such as Ostatni Etap (Wanda Jakubowska, 1948) or The Search (Fred Zinnemann, 1948) develop their stories without mentioning the Holocaust. The former, filmed in Auschwitz, tells the stories of a group of Polish women in the camp, among whom Jewish women were the majority of the prisoners; the latter tells the story of a boy who has been liberated from a camp and, with a soldier's help, is looking for his family. These two examples illustrate the difficulty of expressing through cinematography a process of genocide in the moments following the end of the extermination. This example conveys the limitations and contributions of the cinema to the process of coming to terms with the events of genocide or mass atrocity, and to the debate about these recent pasts. That is why we must distinguish between the production of the film and the uses and distribution of these films. In a recent interview included with the DVD edition of La Noche de Los Lápices, Héctor Olivera, the director, states that what motivated him to make the film was not his familiarity to the topic; rather, while reading the book by the same name, he noted that there was material for a film. He says it was his "product instinct" that 
inspired him. At the same time, this film has been used in different schools and educational establishments for didactic purposes that may be different from the purposes the director had in mind. That is, the way a film is circulated, used, and adapted can often differ from the intentions of its creator; thus different interpretations arise each time and at each place. As Peter Burke ${ }^{48}$ states, before studying the film as a document, you have to study the director.

Regarding the form in which the 'theory of the two demons' was presented, an examination of the way in which it was presented is warranted, since there are several points of view to keep in mind when this interpretation is put forward. The 'theory of the two demons', as an attempt to explain the facts, has two foundations: first, the decrees of the democratically elected President Raúl Alfonsín, who promoted criminal prosecution of the upper echelons of the anti-government armed groups along with the leadership of the armed forces; and second, the prologue of Nunca Más, the final report of the CONADEP (National Commission on the Disappeared Persons) truth commission that equated left-wing violence with right-wing violence. In both cases, the left and right are equally demonized and society is positioned as an innocent victim overwhelmed by these two demons.

This interpretation can be considered in various ways. In the case of filmmaking, we see very good 'good guys' and very bad 'bad guys' (especially evident in La Noche de Los Lápices). Olivera's instinct is illustrated by certain dramatic codes; that is, in order for the drama to gather strength, one of the basic rules of screenwriting is to consider the character of the protagonists. This principle is used as a means for achieving emotive effect, in order for the viewers to identify with the young characters. The same principal can be attributed to La Historia Oficial where the melodramatic form is adopted. These features are due to the fact that film does not show us history in a macro form and with the aim of historical 'objectivity', but by means of the avatars of individuals, men or women, who "are made to seem important because they have been singled out by the camera and appear before us in such a large image on the screen". ${ }^{49}$ Personification, which also motivates identification on the part of the filmgoer, is converted into a device for dealing with more general problems; in the resolution of the individual problem, the historical problem is resolved. Given that a film cannot reveal historical totality, what do certain personifications enable us to tell and show about historical processes? Many of the dramatizations of the characters and their ways of speaking and acting arise more from the diegetic mode of the cinema, the story-world created by each film, than from an intention to reproduce the past with accuracy.

Returning to the analysis relative to the depoliticization of identities, there are various elements to consider. In the 'theory of the two demons', as presented in the documents quoted, and the 'innocent victims' and the society unaware of the facts, a 'demon of the left' was established. Historically, the left-wing armed organizations have no place in the stories of the films analyzed above. Instead to make more complex the activism of the 1970s, the films portray the activism by telling about the work in slums or referring to particular demands such as the campaign for the student bus pass. The closing of an era is clear in the case of film; by not referring to the immediate past, the stories are completely de-historicized, declining all mention of social, national, and continental struggles. In many films, such as Los Días de Junio, references to the past are cast as 'illusions', the illusions that used to exist. That is, political plans and social movements are reduced to simple 'illusions' and utopias.

In conclusion, in 1980s Argentine cinema, filmmakers present us with a wide range of actors perpetrators, accomplices, and victims - allowing us to study various ways of understanding the recent past in a post-genocidal society. With many of these films produced more than twenty years ago, the films analyzed here can be regarded as documents of the early years of the democracy and the climate of that time, or as clear efforts to deal with the recent past. Thus, there is no film that has an unambiguous story. The films in this group form a mosaic, and it is in their association, and their distinctiveness, that we can study the practice of genocide. Clearly, the production of films, the practice of art, also has responsibilities; outside of the motivations that each director may have for pursuing a certain film project, s/he is not relieved of responsibility for the narrative that is placed in circulation: "all filmmakers, or almost all, make their movies thinking that an audience will see and accept them (...); put differently, the filmmaker is necessarily aware of his inclusion in society and of the responsibility that this entails." ${ }^{50}$

One could think that many of the films crafted during this era were positioned in the political correctness of their time, without questioning the 'official' readings referring to the 'innocent victims', while others, perhaps more in the documentary style, take positions against this, seeking to redeem a militant activism and a political plan. Let us recall that behind the production of a film there are a great many interests and 
motivations in play; nevertheless, the films presented here recorded different aesthetics and modalities that later would be continued, responded to, or refuted in subsequent productions.

As well as the criticisms that have been made, we must remember that a film is never a comprehensive reiteration of the past; a motion picture is an interpretation, a condensation, an approximation as well as an evocation. The 'silver screen' can only suggest what happened. Therefore, the principles mentioned above must always be kept in mind in the analytic task. That is why, when studying film productions, one must understand them not only as a consumer product or a work of art. Movies are also, according to Peter Burke, only partly historical documents, and as such they always must be compared and contrasted with other sources. The historical film, or period drama, must become part of the body of knowledge of the subject, must be discussed along with other pre-existing texts, and must also generate controversies with the aim of inspiring new inquiries. As Marc Ferro has noted, ${ }^{51}$ we know that film can be a valuable "revealing agent", making various areas of reality visible on the screen, even some areas that the director himself does not see or is unaware of - hence the need to compare and contrast film with other sources and social theories. In that sense, this article has attempted to add strength to such an overview.

\section{End Notes}

1. Classical authors, like Marc Ferro or Pierre Sorlin, have studied the historical film. However, from a sociological perspective, all kinds of movies, as a product of a symbolic and social imaginary, can be studied.

2. Robert Rosenstone, El pasado en imágenes (Barcelona: Ariel, 1997).

3. Annette Insdorf, Indelible Shadows: Film and the Holocaust (Cambridge: Cambridge University Press, 2002).

4. The theory of the two demons (Spanish: Teoría de los dos demonios) is a rhetorical device used in Argentine political discourse to disqualify arguments that appear to morally equate violent political subversion with illegal repressive activities carried out by the state.

5. Mariana Amieva, Gabriela Arreseygor, Raúl Finkel, and Samanta Salvatori, "Cine y memoria (1983-2006)," in Sandra Raggio and Samanta Salvatori, eds., La última dictadura militar en Argentina (Rosario: Homo Sapiens, 2009).

6. Federico Lorenz, “'Tomala vos, dámela a mi,' La noche de los lápices: el deber de memoria y las escuelas,” in Elizabeth Jelin and Federico Lorenz, eds., Educación y memoria. La escuela elabora el pasado (Madrid: Siglo XXI, 2004).

7. Founded in 1891, the Radical Civic Union is one of the oldest Argentinean political parties. In 1916 it won the first presidential elections with universal suffrage under one of its celebrated leaders, Hipólito Yrigoyen. In October 1983, the party won the presidential election with the formula Raúl Alfonsín - Victor Martinez.

8. The prologue to Nunca Más, attributed to Ernesto Sábato, states that "to the crimes of the terrorists, the Armed Forces replied with a terrorism infinitely worse than the one being fought against (...) As for the society, the idea of vulnerability was taking root, the dark fear that anybody, however innocent he might be, could fall into that endless witch-hunt." Conadep, Nunca Más (Buenos Aires: Eudeba, 1984).

9. Films also signify, by virtue of the uses made of them, in light of the specifics of their distribution and reception, as for example with the 'pedagogical' work done by Gillo Pontecorvo's La battaglia di Algeri (1966) in Argentine military schools.

10. Rosenstone, El pasado, p. 46.

11. Daniel Feierstein, El genocido como práctica social (Buenos Aires: FCE, 2007).

12. "The reorganizing genocide operates towards the interior of a society already constituted, a preexisting nation-state, and it seeks to refund social relations, the links, codes, daily life and the political mediations, in sum the concrete exercising of power in said society." Feierstein, ibid., p. 100.

13. For "use" I mean the use of film as political space for discussion and debate. In short, film serves as a revolutionary tool.

14. The premiere in 1984 of Solanas' film Los hijos de Fierro-filmed in 1975-did not signify the comeback of the Grupo Cine Liberación. The Grupo Cine Liberación (Liberation Film Group) was an Argentinean film movement founded during the 1960's by Fernando Pino Solanas, Ocatvio Getino and Gerardo Vallejo. The Group intervened in political debates of the period and published a series of articles about the 'third cinema' and cinema and the revolution, among others. It was linked with Peronist left, and its most famous work is the film "La hora de los hornos" (The Hour of the furnaces).

15. Lev Vygotsky, Psicología del arte (Buenos Aires: Siglo XXI, 2003).

16. Giorgio Agamben, “¿Qué es un campo?” in Medios sin fin (Valencia: Pre Textos, 2001).

17. Pilar Calveiro, Poder y desaparición (Buenos Aires: Colihue, 1998), p. 147. [author’s translation]

18. In the recent film Garage Olimpo (Marco Bechis, 1999), a reconstruction of the 'death flights' may be seen rendered in images.

19. A traditional Argentine grill used for cooking meat. In the lexicon of the perpetrators, parrilla refers to the metal table on which the detainees were laid out to be tortured. Feitlowitz, A lexicon of terror. Argentina and the legacies of tortures (New York: Oxford University Press),, p.57. 
20. Dagmar Hagelin was an Argentine-Swedish teenager who was kidnapped by a task group commanded by Alfredo Astiz and then taken to ESMA. Her case had international consequences. To this day, the young woman continues to be among the disappeared.

21. Pavlovsky is an important playwright, actor and Argentine psychiatrist; he is the creator of the psychodrama in Latin America.

22. The National Reorganization Process was the name used by its leaders for the military dictatorship that ruled Argentina from 1976 to 1983. It is suggestive to declare in the group's own name the reorganization intentions of the leaders; moreover their objective wasn't to transform a particular group but the entire nation.

23. Eduardo Pavlovsky, El teatro de Eduardo Pavlovsky. El Señor Galíndez y Pablo (Buenos Aires: Ediciones búsqueda, 1986).

24. The repressors and the concentration camp personnel used to use animal names as nicknames.

25. It is important to remark that the actress who interpreted Ana is Chunchuna Villafañe. In 1976, after the coup, Villafañe was threatened and went to exile with her husband, the director Pino Solanas. La historia oficial was her first movie made after her comeback.

26. El Atlético (The Athletics) was a center of detention and torture that operated in the city of Buenos Aires. This center operated from mid-1976 until December 1977. In late 1979 the building was demolished to construct a highway.

27. Robert Lifton and Eric Markusen, The Genocidal Mentality (New York: Basic Books, 1990).

28. The National Security Doctrine was a strategy prepared by the United States government for Latin America during the Cold War. It focused on identifying and destroying internal 'enemies' as part of the struggle against communism.

29. Yves Ternon, El estado criminal. Los genocidios en el siglo XX (Barcelona: Peninsula, 1995), p, 121.

30. Robert Lifton, The Nazi Doctors (New York: Basic Books, 2000), p. 491.

31. Robert Lifton, idem, p. 418.

32. On the Poch case, see Página/12 for September 24, 2009, http://www.pagina12.com.ar/diario/elpais/1-132314-2009-09-24.html.

33. Years later, in Garage Olimpo, the workers at the camp clock out when they finish their work hours.

34. Helen Fein, cited in Zygmunt Bauman, Modernidad y Holocausto (Madrid: Sequitur, 1997), p. 49.

35. During the last dictatorship, Argentina was divided in five military zones. Every zone was under the mandate of an Army Corps.

36. This operative was carried out in 1975, during the democratic government of Isabel Perón, in order to repress the ERP (Ejército Revolucionario del Pueblo) in the Argentinean northern province of Tucumán.

37. Ternon, El estado criminal.

38. Between 1976 and 1977, Marta Bettini suffered the kidnapping of her mother, her husband, her son and her son-in-law.

39. Raphael Lemkin, El dominio del Eje en la Europa ocupada (Buenos Aires: Prometeo-Eduntref, 2009).

40. Another film by Carlos Echeverría, Pacto de silencio (2004), centered on the case of the former Nazi Erich Priebke, shows us, in archival film images, ceremonies and events at which Barbieris, Castelli and Priebke embrace each other.

41. Feierstein, El genocidio.

42. Lior Zylberman, 'El desaparecido en el Nuevo Cine Argentino', paper presented at the Second International Conference Analysis of Genocidal Social Practices, Buenos Aires, 2007.

43. A youth movement inspired by the ideas of Ernesto Che Guevara.

44. Eva Perón or 'Evita', was the second wife of Argentine president Juan Domingo Perón. She spread the Peronist ideals through her work in the Eva Perón Foundation during the first government of his husband (1946-1952). She died at the age of 33 in 1952.

45. Montoneros was a Peronist armed political group, active in the 1970s, that outnumbered other political organizations.

46. Hebe de Bonafini is the President of the Association of Mothers of Plaza de Mayo.

47. Alfredo Palacios (1880-1965) was an Argentine socialist politician. In 1904 he was elected in the Parliament, becoming the first socialist in the Argentine Congress and in the Americas. Palacios helped create many laws regulating working hours and others benefits for workers.

48. Rosenstone, El pasado, p. 50.

49. Jacques Aumont, Las teorías de los cineastas (Barcelona: Paidós, 2004), pp. 115-116.

50. Ferro, Historia contemporánea. 